\title{
RESEARCH \\ Optimal parameters for lateral oblique radiographs of rat mandibles
}

\author{
CRW Mahl and V Fontanella* \\ School of Dentistry, Universidade Federal do Rio Grande do Sul, Rua Ramiro Barcelos, Porto Alegre, RS, Brazil
}

\begin{abstract}
Objective: To establish optimal exposure parameters for lateral oblique radiographs of rat mandibles using an intraoral X-ray machine.

Methods: A positioning apparatus, previously tested for its reproducibility, was used to obtain radiographs of four heads of formaldehyde-preserved Wistar rats. Radiographs were exposed at $50 \mathrm{kV}$ and $8 \mathrm{~mA}$ using four size 2 films (Insight, Ektaspeed Plus, Ultraspeed and D-Speed; Eastman Kodak Co., Rochester, NY), two focal distances $(30 \mathrm{~cm}$ and $60 \mathrm{~cm})$ and seven exposure times $(0.6 \mathrm{~s}, 0.7 \mathrm{~s}, 0.8 \mathrm{~s}, 1.0 \mathrm{~s}, 1.5 \mathrm{~s}, 2.0 \mathrm{~s}$ and $2.5 \mathrm{~s})$. The radiographs were evaluated by two examiners and scored for image quality: 1 , very poor; 2 , poor; 3 , fair; 4 , good; and 5, excellent. The evaluations were repeated at 30 days.

Results: Intraobserver reproducibility was substantial (kappa $=0.798$ and 0.667). Also, the two examiners showed substantial agreement (kappa $=0.726$ ). There was a significant difference $(\alpha=1 \%)$ between the scores for the films under study. At a $30 \mathrm{~cm}$ distance, Espeed films had mean scores of 4 and 5 at $0.8 \mathrm{~s}$ and $1 \mathrm{~s}$ exposure times, and D-speed films, at $1.5 \mathrm{~s}, 2 \mathrm{~s}$ and $2.5 \mathrm{~s}$ exposure times. At a $60 \mathrm{~cm}$ distance, the best results were found for Espeed films at $2.0 \mathrm{~s}$ and $2.5 \mathrm{~s}$ exposure times.

Conclusion: The films under study did not show any significant difference in the quality of rat mandible images as long as exposure times were adequate to their sensitivity and focal distance. Dentomaxillofacial Radiology (2008) 37, 224-227. doi: 10.1259/dmfr/32763038
\end{abstract}

Keywords: radiography; rats, Wistar; mandible; X-ray film

\section{Introduction}

The use of animal models is fundamental to establish the scientific bases of the research process. Of several animal models, rats are most often used because they are low cost, easy to manage animals. ${ }^{1}$ However, the radiographic procedures usually adopted to obtain linear measures of larger animals and human beings are complicated in rats because of their small size. ${ }^{2}$ Moreover, low-power X-ray machines have to be used to record detailed images of anatomical structures, such as the cementoenamel junction, ${ }^{3-6}$ and a positioning device has to be used to ensure reproducibility of radiographic exposures in the same animal. ${ }^{5}$ However, few studies in the literature ${ }^{3,5}$ report attempts to establish geometric standardization of the process of obtaining radiographs of the mandible of live rats.

Because of the difficulties posed by in vivo radiographs, experimental bone resorption studies are often

*Correspondence to: Vania Fontanella, Rua Cel. Paulino Teixeira 169/403, 90420-160, Porto Alegre, RS - Brazil; E-mail: vaniafontanella@terra.com.br Received 4 October 2006; revised 23 August 2007; accepted 29 August 2007 conducted with radiographs of necropsy material, which can be used for cross-sectional studies but limits longitudinal evaluations. ${ }^{2,3}$

Fontanella et $\mathrm{al}^{7}$ developed and tested a positioning apparatus for oblique lateral radiographs of the mandible using five formaldehyde-preserved heads of rats and dental films. The tested apparatus ensured standardization for the detection of subtle bone losses using digital subtraction of images. However, it is still unclear which radiographic parameters provide the best results. Therefore, the purpose of this study was to establish the optimal parameters of exposure time, focal distance and type of film for radiographs of rat mandibles using an intraoral X-ray machine.

\section{Materials and methods}

The positioning apparatus tested by Fontanella et $\mathrm{al}^{7}$ was used to obtain the radiographs. Each rat head was 
positioned and fixed by three metal clamps placed in the interincisal space of the upper central incisors (occluded), and the right and left auditory canals. The midsagittal plane of the head was parallel to the film packet and the X-ray tube was adapted to a support so that the vertical angle was $-30^{\circ}$ (Figure 1).

Four heads of formaldehyde-preserved Wistar rats were used. Radiographs were exposed at $50 \mathrm{kVp}$ and $8 \mathrm{~mA}$ (Spectro II; Dabi Atlante, Ribeirão Preto, Brazil) using four types of film (Eastman Kodak Co., Rochester, NY), two of which were D-speed films (Ultraspeed and D-Speed) and two E-speed films (Insight and Ektaspeed Plus), at seven different exposure times $(0.6 \mathrm{~s}, 0.7 \mathrm{~s}, 0.8 \mathrm{~s}, 1 \mathrm{~s}, 1.5 \mathrm{~s}, 2 \mathrm{~s}$ and $2.5 \mathrm{~s})$, two different focal distances $(30 \mathrm{~cm}$ and $60 \mathrm{~cm}$ ) and a vertical angle of $-30^{\circ}$. The combination of these parameters resulted in 56 radiographs of each head, totalling 224 radiographs. The films were processed using the time-temperature method and fresh processing solutions (Eastman Kodak Co.).

An X-ray film viewer was used to analyse radiographs randomly in a darkened room. Two examiners, both experienced oral radiologists, used a magnifying glass and classified image quality according to a fivepoint scale: 1 , very poor; 2 , poor; 3 , fair; 4 , good; and 5 , excellent.

The evaluations were repeated at 30 days and intraand interobserver reproducibility was calculated using kappa agreement. The Kruskal-Wallis test was used to analyse the scores assigned by examiners and to

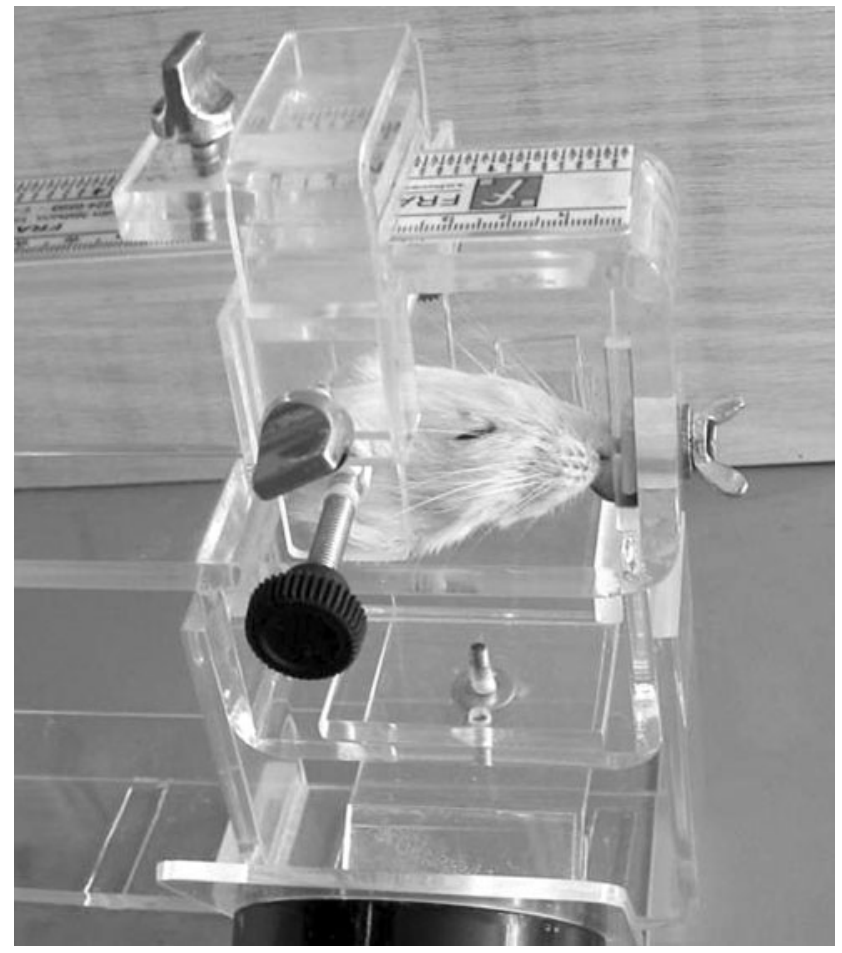

Figure 1 Rat head positioned in apparatus determine the optimal combination of exposure parameters.

\section{Results}

The analysis of reproducibility showed substantial ${ }^{8}$ intraobserver agreement (kappa $=0.798$ and 0.667). Also interobserver agreement was substantial (kappa $=0.726$ ). Median scores assigned twice to each image by the two examiners were used for the analysis of parameter combinations (Tables 1 amd 2). A significant difference in scores was found in the comparison between the films under study (non-parametric Kruskal-Wallis test). At a $30 \mathrm{~cm}$ distance (Table 1), Ultraspeed and D-Speed scores were different from Insight and Ektaspeed Plus scores, except for the $1.5 \mathrm{~s}$ exposure time. The images obtained with D-speed films were significantly worse at shorter times and significantly better at $2.0 \mathrm{~s}$ and $2.5 \mathrm{~s}$ exposure times than the images obtained with E-speed films. At a $60 \mathrm{~cm}$ distance (Table 2), film speed did not show statistically

Table 1 Results of Kruskal-Wallis test: comparisons between films and exposure times at $30 \mathrm{~cm}$ focal distance

\begin{tabular}{|c|c|c|c|c|c|}
\hline Film & $\mathrm{n}$ & $\begin{array}{l}\text { Mean } \\
\text { score }\end{array}$ & $\begin{array}{l}\text { Standard } \\
\text { deviation }\end{array}$ & $\begin{array}{l}\text { Mean } \\
\text { rank }\end{array}$ & $\mathrm{P}$ \\
\hline \multicolumn{6}{|l|}{0.6 s time } \\
\hline D-speed & 4 & 1.3 & 0.5 & $5.1^{\mathrm{A}}$ & \multirow[t]{4}{*}{0.024} \\
\hline Ultraspeed & 4 & 1.3 & 0.5 & $5.1^{\mathrm{A}}$ & \\
\hline Insight & 4 & 2.8 & 1.0 & $12.4^{\mathrm{B}}$ & \\
\hline $\begin{array}{l}\text { Ektaspeed Plus } \\
0.7 \text { s time }\end{array}$ & 4 & 2.5 & 1.0 & $11.4^{\mathrm{B}}$ & \\
\hline D-speed & 4 & 1.3 & 0.5 & $3.9^{\mathrm{A}}$ & \multirow[t]{4}{*}{0.012} \\
\hline Ultraspeed & 4 & 1.8 & 1.0 & $5.9^{\mathrm{A}}$ & \\
\hline Insight & 4 & 3.5 & 1.0 & $12.2^{\mathrm{B}}$ & \\
\hline Ektaspeed Plus & 4 & 3.3 & 0.5 & $12.0^{\mathrm{B}}$ & \\
\hline D-speed & 4 & 2.0 & 0.0 & $4.50^{\mathrm{A}}$ & \multirow{4}{*}{0.005} \\
\hline Ultraspeed & 4 & 2.0 & 0.8 & $4.50^{\mathrm{A}}$ & \\
\hline Insight & 4 & 4.5 & 0.6 & $13.50^{\mathrm{B}}$ & \\
\hline Ektaspeed Plus & 4 & 4.0 & 0.0 & $11.50^{\mathrm{B}}$ & \\
\hline D-speed & 4 & 3.0 & 0.0 & $4.00^{\mathrm{A}}$ & \multirow[t]{4}{*}{0.005} \\
\hline Ultraspeed & 4 & 3.3 & 0.5 & $5.25^{\mathrm{A}}$ & \\
\hline Insight & 4 & 4.5 & 0.6 & $11.25^{\mathrm{B}}$ & \\
\hline $\begin{array}{l}\text { Ektaspeed Plus } \\
1.5 \text { s time }\end{array}$ & 4 & 5.0 & 0.0 & $13.50^{\mathrm{B}}$ & \\
\hline D-speed & 4 & 4.3 & 0.5 & 9.0 & \multirow[t]{4}{*}{0.193} \\
\hline Ultraspeed & 4 & 4.8 & 0.5 & 12.0 & \\
\hline Insight & 4 & 4.0 & 0.8 & 7.7 & \\
\hline $\begin{array}{l}\text { Ektaspeed Plus } \\
2.0 \text { s time }\end{array}$ & 4 & 3.5 & 1.0 & 5.2 & \\
\hline D-speed & 4 & 4.3 & 1.0 & $11.50^{\mathrm{A}}$ & \multirow[t]{4}{*}{0.005} \\
\hline Ultraspeed & 4 & 5.0 & 0.0 & $13.50^{\mathrm{A}}$ & \\
\hline Insight & 4 & 1.3 & 0.5 & $4.50^{\mathrm{B}}$ & \\
\hline $\begin{array}{l}\text { Ektaspeed Plus } \\
2.5 \text { s time }\end{array}$ & 4 & 1.3 & 0.5 & $4.50^{\mathrm{B}}$ & \\
\hline D-speed & 4 & 4.0 & 1.4 & $12.25^{\mathrm{A}}$ & \multirow{4}{*}{0.004} \\
\hline Ultraspeed & 4 & 4.5 & 0.6 & $12.75^{\mathrm{A}}$ & \\
\hline Insight & 4 & 1.0 & 0.0 & $4.50^{\mathrm{B}}$ & \\
\hline Ektaspeed Plus & 4 & 1.0 & 0.0 & $4.50^{\mathrm{B}}$ & \\
\hline
\end{tabular}

Mean ranks followed by different letters differ significantly $(P<0.05)$ 
Table 2 Results of Kruskal-Wallis test: comparisons between films and exposure times at $60 \mathrm{~cm}$ focal distance

\begin{tabular}{|c|c|c|c|c|c|}
\hline Film & $\mathrm{n}$ & $\begin{array}{l}\text { Mean } \\
\text { score }\end{array}$ & $\begin{array}{l}\text { Standard } \\
\text { deviation }\end{array}$ & $\begin{array}{l}\text { Mean } \\
\text { rank }\end{array}$ & $\mathrm{P}$ \\
\hline \multicolumn{6}{|l|}{$0.6 \mathrm{~s}$ time } \\
\hline D-speed & 4 & 1.0 & 0.0 & 7.50 & \multirow[t]{4}{*}{0.542} \\
\hline Ultraspeed & 4 & 1.0 & 0.0 & 7.50 & \\
\hline Insight & 4 & 1.3 & 0.5 & 9.50 & \\
\hline Ektaspeed Plus & 4 & 1.3 & 0.5 & 9.50 & \\
\hline \multicolumn{6}{|l|}{$0.7 \mathrm{~s}$ time } \\
\hline D-speed & 4 & 1.0 & 0.0 & 7.50 & \multirow[t]{4}{*}{0.542} \\
\hline Ultraspeed & 4 & 1.0 & 0.0 & 7.50 & \\
\hline Insight & 4 & 1.3 & 0.5 & 9.50 & \\
\hline $\begin{array}{l}\text { Ektaspeed Plus } \\
\text { os s time }\end{array}$ & \multirow{2}{*}{\multicolumn{2}{|c|}{0.8 s time }} & 0.5 & 9.50 & \\
\hline $\begin{array}{l}\text { O.8 s time } \\
\text { D-speed }\end{array}$ & 4 & 1.0 & 0.0 & 7.50 & \\
\hline Ultraspeed & 4 & 1.0 & 0.0 & 7.50 & \multirow{3}{*}{0.543} \\
\hline Insight & 4 & 1.5 & 1.0 & 9.63 & \\
\hline Ektaspeed Plus & 4 & 1.3 & 0.5 & 9.38 & \\
\hline \multicolumn{6}{|l|}{$1.0 \mathrm{~s}$ time } \\
\hline D-speed & 4 & 1.0 & 0.0 & 5.0 & \multirow[t]{4}{*}{0.542} \\
\hline Ultraspeed & 4 & 1.3 & 0.5 & 6.7 & \\
\hline Insight & 4 & 2.3 & 1.9 & 9.5 & \\
\hline Ektaspeed Plus & 4 & 2.3 & 0.5 & 12.7 & \\
\hline \multicolumn{5}{|l|}{$1.5 \mathrm{~s}$ time } & \\
\hline $\begin{array}{l}\text { D-speed } \\
\text { Ultraspeed }\end{array}$ & 4 & 1.8 & 0.5 & $5.4^{\mathrm{A}}$ & \multirow{3}{*}{0.012} \\
\hline Insight & 4 & 3.0 & 0.8 & $11.1^{\mathrm{B}}$ & \\
\hline Ektaspeed Plus & 4 & 3.5 & 0.6 & $13.2^{\mathrm{B}}$ & \\
\hline \multicolumn{6}{|l|}{$2.0 \mathrm{~s}$ time } \\
\hline D-speed & 4 & 2.3 & 0.5 & $3.5^{\mathrm{A}}$ & \multirow[t]{5}{*}{0.006} \\
\hline Ultraspeed & 4 & 2.8 & 0.5 & $5.5^{\mathrm{A}}$ & \\
\hline Insight & 4 & 4.3 & 0.5 & $12.0^{\mathrm{B}}$ & \\
\hline Ektaspeed Plus & 4 & 4.5 & 0.6 & $13.0^{\mathrm{B}}$ & \\
\hline \multicolumn{5}{|l|}{$2.5 \mathrm{~s}$ time } & \\
\hline D-speed & 4 & 2.8 & 1.0 & $5.1^{\mathrm{A}}$ & \multirow[t]{4}{*}{0.024} \\
\hline Ultraspeed & 4 & 2.8 & 1.0 & $5.1^{\mathrm{A}}$ & \\
\hline Insight & 4 & 5.0 & 0.0 & $12.4^{\mathrm{B}}$ & \\
\hline Ektaspeed Plus & 4 & 4.8 & 0.5 & $11.4^{\mathrm{B}}$ & \\
\hline
\end{tabular}

Mean ranks followed by different letters differ significantly $(P<0.05)$

different results up to $1 \mathrm{~s}$ exposure time. At other exposure times, the use of E-speed films resulted in statistically better images than those obtained with Dspeed films.

The images with the greatest scores indicated the optimal combination of film type and exposure time for each of the distances used. At a $30 \mathrm{~cm}$ distance, E-speed films had mean scores of 4 and 5 at $0.8 \mathrm{~s}$ and $1 \mathrm{~s}$ exposure times, and D-speed films, at $1.5 \mathrm{~s}, 2 \mathrm{~s}$ and $2.5 \mathrm{~s}$ exposure times. At a $60 \mathrm{~cm}$ distance, the best results (mean scores: 4.5 and 4.8) were found for Espeed films at $2.0 \mathrm{~s}$ and $2.5 \mathrm{~s}$ exposure times.

\section{References}

1. El Montaser MA, Devlin H, Sloan P, Dickinson MR. Pattern of healing of calvarial bone in the rat following application of the Er:YAG laser. Lasers Surg Med 1997; 21: 255-261.

2. Gaio EJ, Fernandes MI, Oppermann RV, Rados PV, Rösing CK. Análise comparativa da altura óssea histométrica e morfométrica na periodontite induzida em ratos. Braz Oral Res 2004; 18: 65.

3. Gaegauf-Zollinger R, Burckhardt JJ, Guggenheim B. Radiographic measurements of alveolar bone loss in the rat. Arch Oral Biol 1982; 27: 651-658.

\section{Discussion}

Radiographic studies help in the early detection of bone tissue changes in animal models. When radiographic procedures are standardized, variations in mineral content can be detected using digital subtraction radiography. ${ }^{9}$

The standardization of radiographic exposures in animal models has been investigated, but procedures still require high-cost equipment and are time-consuming. ${ }^{3}$ Radiographic studies with rats have used mammography films, ${ }^{5}$ dental radiography films, ${ }^{10-12}$ intraoral $^{4}$ or oclusal, ${ }^{12,13}$ and low kilovoltage X-ray sources. ${ }^{14-16}$ These studies do not seem to have reached satisfactory results - as they were not employed in more recent studies - and other methods to obtain images, such as X-ray absorptiometry, bone densitometry ${ }^{19-21}$ and micro X-ray $\mathrm{CT}^{22-25}$ have been investigated. However, these methods require special installations for their use with animals and have a high operational cost. Therefore, several studies with rats do not perform radiographic evaluations to obtain longitudinal measures and assess bone density.

The term "radiographic image quality" describes the subjective analysis of images, directly affected by density, contrast and sharpness or by the level of detail observed in the images of target structures. ${ }^{26}$ The lack of standardization in these parameters further restricts the interpretation of bone gain or loss. ${ }^{27}$

In the present study, D-speed and E-speed radiographic films are not significantly different, not even in terms of diagnostic efficacy in human patients, ${ }^{28}$ as long as exposure times are adjusted. ${ }^{29-30}$

The results of this study revealed that at a $30 \mathrm{~cm}$ distance and $1.5 \mathrm{~s}$ exposure time, D- and E-speed film images are similar. At short exposure times, D-speed film images are worse (too light) than images obtained with E-speed films. At longer exposure times $(2.0 \mathrm{~s}$ and $2.5 \mathrm{~s}) \mathrm{D}$-speed film images are better than images obtained with E-speed films, which were too dark. At a $60 \mathrm{~cm}$ distance, E-speed films had the greatest scores at $2.0 \mathrm{~s}$ and $2.5 \mathrm{~s}$ exposure times.

In conclusion, this study found no significant difference in the quality of the image of rat mandibles among the four films when exposure times were adjusted to the film and focal distance. The best quality images were obtained using $30 \mathrm{~cm}$ distance, Ektaspeed Plus film with $1.0 \mathrm{~s}$ exposure time, and Ultraspeed film with $2.0 \mathrm{~s}$ exposure time.

4. Segawa H. Fundamental study of alveolar bone measurements in the hamster using an apparatus for intraoral radiography. Ou Daigaku Shigakushi 1990; 17: 77-94.

5. Reymond F, Cimasoni G. Radiographic measurements of alveolar bone loss in the living rat. J Periodontol 1997; 68: $141-144$.

6. Bresin A, Kiliaridis S, Strid KG. Effect of masticatory function on the internal bone structure in the mandible of the growing rat. Eur J Oral Sci 1999; 107: 35-44. 
7. Fontanella VR, Mahl CRW, Padilha DMP, Travessas JA. Evaluation of an apparatus for standardized radiographs of rat mandible. Proceedings of the 15th International Congress of Dentomaxillofacial Radiology; 2005, Cape Town, South Africa, Medimond: Bologna, 2005.

8. Landis JR, Koch GG. The measurement of observer agreement for categorical data. Biometrics 1977; 33: 159-174.

9. Southard KA, Southard TE. Detection of simulated osteoporosis in dog alveolar bone with the use of digital subtraction. Oral Surg Oral Med Oral Pathol 1994; 77: 412-418.

10. Serota KS, Jeffcoat MK, Kaplan ML. Intraoral radiography of molar teeth in rats. Lab Anim Sci 1981; 31: 507-509.

11. Nishimura I, Damiani PJ, Atwood DA. Resorption of residual ridges (RRR) in rats. J Dent Res 1987; 66: 1753-1757.

12. Bodner L, Kaffe I, Littner MM, Cohen J. Extraction site healing in rats. A radiologic densitometric study. Oral Surg Oral Med Oral Pathol 1993; 75: 367-372.

13. Junqueira JC, Mancini MN, Carvalho YR, Anbinder AL, Balducci I, Rocha RF. Effects of simvastatin on bone regeneration in the mandibles of ovariectomized rats and on blood cholesterol levels. J Oral Sci 2002; 44: 117-124.

14. Maki K, Nishioka T, Shioiri E, Takahashi T, Kimura M. Effects of dietary consistency on the mandible of rats at the growth stage: computed X-ray densitometric and cephalometric analysis. Angle Orthod 2002; 72: 468-475.

15. Petrikowski CG, Overton TR. Quantitative radiographic changes in the mandible, femur and vertebra in lactating rats fed a lowcalcium diet. Dentomaxillofac Radiol 1996; 25: 136-145.

16. Moriya Y, Ito K, Murai S. Effects of experimental osteoporosis on alveolar bone loss in rats. J Oral Sci 1998; 40: 171-175.

17. Sakakura Y, Shide N, Tsuruga E, Irie K, Yajima T. Effects of running exercise on the mandible and tibia of ovariectomized rats. $J$ Bone Miner Metab 2001; 19: 159-167.

18. Hidaka S, Okamoto Y, Miyazaki K, Uesugi T. Evaluation of a soybean product fujiflavone $\mathrm{P} 40$ as an antiosteoporotic agent in rats. Phytother Res 2003; 17: 112-119.

19. Jiang G, Matsumoto H, Fujii A. Mandible bone loss in osteoporosis rats. J Bone Miner Metab 2003; 21: 388-395.
20. Mardas N, Kostopoulos L, Stavropoulos A, Karring T. Osteogenesis by guided tissue regeneration and demineralized bone matrix. J Clin Periodontol 2003; 30: 176-183.

21. Elsubeihi ES, Heersche JN. Quantitative assessment of postextraction healing and alveolar ridge remodelling of the mandible in female rats. Arch Oral Biol 2004; 49: 401-412.

22. Kuroda S, Mukohyama H, Kondo H, Aoki K, Ohya K, Ohyama $\mathrm{T}$, Kasugai S. Bone mineral density of the mandible in ovariectomized rats: analyses using dual energy X-ray absorptiometry and peripheral quantitative computed tomography. Oral Dis 2003; 9: 24-28.

23. Nakano H, Watahiki J, Kubota M, Maki K, Shibasaki Y, Hatcher D, Miller AJ. Micro X-ray computed tomography analysis for the evaluation of asymmetrical condylar growth in the rat. Orthod Craniofac Res 2003; 6: 168-172.

24. Tanaka M, Toyooka E, Kohno S, Ozawa H, Ejiri S. Long-term changes in trabecular structure of aged rat alveolar bone after ovariectomy. Oral Surg Oral Med Oral Pathol Oral Radiol Endod 2003; 95: 495-502.

25. Yang J, Pham SM, Crabbe DL. Effects of oestrogen deficiency on rat mandibular and tibial microarchitecture. Dentomaxillofac Radiol 2003; 32: 247-251.

26. Whaites E. Essentials of dental radiography and radiology (3rd edn). Edinburgh: Churchill Livingstone, 2002.

27. Jeffcoat MK, Reddy MS. Digital subtraction radiography for longitudinal assessment of peri-implant bone change: method and validation. Adv Dent Res 1993; 7: 196-201.

28. Ardakani FE, Davari A, Goodarzipour D, Goodarzipour K, Fallahzadeh H. Evaluation of the diagnostic advantage of intraoral $\mathrm{D}$ and $\mathrm{E}$ film for detecting interproximal caries. $J$ Contemp Dent Pract 2004; 5: 58-70.

29. Price C. Sensitometric evaluation of a new F-speed dental radiographic film. Dentomaxillofac Radiol 2001; 30: 29-34.

30. Syriopoulos K, Velders XL, Sanderink GCH, van der Stelt PF. Sensitometric and clinical evaluation of a new F-speed dental X-ray film. Dentomaxillofac Radiol 2001; 30: $40-44$. 